\title{
Layers of listening: virtuosity in clinical practice
}

\section{Opinion}

Coming as I have from a musical background, the word "virtuosity" brings to my mind the image of a great violinist or pianist; someone who has practiced so dedicatedly and relentlessly, and knows their stuff so well, that they bring their own emotions to bear with great precision and beauty to the best possible performance. I will never forget the day that I experienced that same virtuosity within myself, practicing psychoanalysis. I had been practicing perhaps for 15 years, and was nearing the end of a difficult session with a man who wanted to leave treatment. I could feel a familiar surge of dread arise, unsure of what to say in light of the treatment destructive resistance. I felt the patient, a frustrated, lonely and unsuccessful man who attacked himself relentlessly, was exacting revenge on me by leaving treatment. By leaving, he could enjoy transferring to me the deep feelings of inadequacy he harboured chronically. My goal was to see if he could successfully transfer the feelings to me, without leaving. It would require bringing out into the open that he wanted me to feel like a failure, rather than enact the feeling by leaving. Towards the middle of the session, I could see that the patient was genuinely frustrated with me. I was working, I thought, masterfully to frustrate him sufficiently that he had to keep explaining himself, until finally, he could concede that I was the failure.

At that moment, I realized that all the disparate parts of my training had coalesced, and that I was able to simultaneously juggle all the pieces into a cohesive whole. First, I had in my mind metatheory, which was guiding my understanding that the patient needed to discharge his negativity into words. Next, I had in my mind my counter transference, which was that I was a failure, and had to adopt the mantle of that feeling to help the patient stay with me. Third, I had my supervisor's voice in my head, including the tone of voice I had learned to emulate in delivering the emotional communications, which I had heard described as "fist of iron, voice of an angel." As I juggled all of these thoughts and emotions, I felt riveted. Watching the patient respond with emotion and by committing to come back was exhilarating. This, I remember thinking, was what virtuosity felt like: knowing, at least for that session, exactly what I was doing, and how, and why. In essence, virtuosity is achieved by adopting progressively deeper and more nuanced levels of listening. Here is the order in which I achieved them in my own training.

\section{Listening to the counter transference}

Learning to listen to your own feelings is difficult if you stumble across some that you are particularly allergic to. For some, it is inadequacy, for others, being left, still others don't like anger, and to some degree we are all hard-wired to want to escape all of the above. One of the most rewarding aspects of training to become psychoanalysis is gaining mastery over your most unwanted feelings, which makes it possible to discern choices instead of getting overwhelmed in light of them. Generally speaking, in the beginning stages of training, most of your counter transference responses will be subjective, that is, to do with you. Like riding a bike, you will feel scared, fascinated, tense, exhilarated at first, and those feelings will be on the front burners, probably, of all your observations. As a student,
Volume 9 Issue 6 - 2018

\author{
Claudia Luiz \\ Licensed Psychoanalyst, USA
}

Correspondence: Claudia Luiz, Licensed Psychoanalyst, USA, Email clujz@verizon.net

Received: February 20, 2018 | Published: November 26, 2018

I was afraid for a long time that my patients would discover me for the ingénue that I was, and leave. Sometimes, it was hard to hear much beyond the clamor of my own insecurity. Once you have gained adeptness and familiarity with your counter transference, however, your own subjective feelings fade into the background more, and it becomes progressively easier to ascertain what the person in the room with you is feeling, until you can more and most easily slip into their consciousness and experience their tension levels through your own psyche.

\section{Listening for the contact}

Listening to metatheory

Listening to technique

\section{Listening to mentors}

Once in the treatment service, I was finally out of the senseless world of illogic and mental chaos. Or so I thought. My first few cases, some of which are still in treatment with me today, were quite psychotic. But I was armed with my modern analytic technique, and it basically directed me to do two things. 1) Follow the contact and 2) ask three object-oriented questions. Easy. Over time, I learned there is more to listening for the contact than measuring a weighty pause or waiting for a question from the patient. I learned to "listen" to the movement of a foot, to a feeling in the room and to my intuition. The more I could listen for, the more I could enter the patient's psychic space. Finding that space makes it much easier to modulate how much (or how little) stimulation the patient needs to keep talking. This is what "following the contact" means to me now.

\section{Control analysis and supervision: listening to mentors}

Supervision is another form of analysis, and what I learned first in supervision was that I did not want to do anything my supervisors recommended. Worse, I did not want to learn anything from them. It actually took me a very long time to understand this about myself. New levels of resistance to teamwork continue to unfurl the more I get analyzed. We are very fortunate that our supervisors work with our own resistances. Ultimately, it makes it possible for us to learn from them. Just as proficiency sight-reading music or driving a car develops naturally, so that you are no longer even conscious of your efforts, so too, I believe, do our supervisor's distinct styles become integrated into our own repertoire. Some of my supervisors' ways of working have become so deeply ingrained and internalized that sometimes I feel as though I channel them in a session. 


\section{The final paper: listening to theory and meta-theory}

I barely read throughout my training, and when I did, I did not remember much. It was only shortly before I graduated that I started to read with a sense of revelation. Once I was finally able to read actively, how I listened to a patient in a session expanded greatly. For example, an obsessive patient who was driving me out of my mind complaining incessantly about a dripping noise in her bedroom became less irritating after I read Freud's Rat Mana. I started to wonder what the plumbing problem symbolized sexually, since this woman had never achieved orgasm. I then also started to listen beyond the complaint to gauge her levels of frustration, hopelessness and obsession. Theory can really expand listening when feelings are engaged.

\section{Putting it all together}

After a heated session with an old patient who was voicing negative feelings about me, about fifteen years into my training, I realized that I had been able to listen simultaneously on about five different levels. I was listening to him, to my counter transference, to what I knew about his character, to theories about what helps with depression and to Dr. Laquercia, who, with both devil tail and angel wings, was sitting on my shoulder helping guide my emotional communications. It was exhilarating to recognize how much I could listen to and use, at once. This past week, a woman suffering from the sudden onset of terrible panic attacks came into my office. She thought that if she could only understand why this horrible thing was happening to her, it might go away. Could I understand it and explain it to her? I had no idea why this woman was suffering, or who she was. I felt only her deep frustration, watching her take a long drink from her bottle of water after I had to tell her that the panic attacks were a mystery to me too. The process of learning how to listen, with all of its discomfort, begins anew with each case. With each new patient, I must tolerate feeling like an ingénue once again, willing myself to tolerate the feelings that the patient has not learned to discern or articulate. The difference now is that my listening is more practiced. I listen now, not only to the nagging sense of insecurity and induced feeling, not only to what the patient wants and my resistance to treating her, not only to what I might know about her problem, but also to the enduring knowledge that my best course of action is to find a way to hear more. To keep listening. I search for a question to keep her talking. One that will not be too painful or too deep but at the same time, not too removed from what she is talking about. I find a neutral question, and she begins to talk. I sit back and listen, a student once again, observing, taking in her rage, waiting for the next resistance and the gradual unfolding of her despair.

\section{Acknowledgments}

None.

\section{Conflicts of interest}

The author declares that there is no conflicts of interest. 